\title{
Dante and the Modalities of Grace
}

Né tra l'ultima notte e 'l primo die sì alto $\mathrm{o}$ sì magnifico processo, o per l'una o per l'altra, fu o fie: ché più largo fu Dio a dar sé stesso per far l'uom sufficiente a rilevarsi, che s'elli avesse sol da sé dimesso ...

(Par. VII.112-17)

1. Preliminary considerations: Singleton, Singletonians and patterns of grace-theological consciousness. 2. Dante and the revised geometry of grace awareness. 3. Dante and the modalities of grace: grace as a principle of encouragement (being under the aspect of fortitude) - grace as a principle of emancipation (being under the aspect of freedom) grace as a principle of ecstasy (being under the aspect of rejoicing). 4. Conclusion: grace as but love by another name.

In 1990 a book appeared which, by way of its knack both of uplifting and of upsetting the reader at the same time, called into question an interpretation of the Commedia in its theological aspect going back through Giuseppe Mazzotta and John Freccero to Charles Singleton in his seminal Journey to Beatrice. The book was Antonio Mastrobuono's Dante's Journey of Sanctification, ${ }^{2}$ which, in the course of

${ }^{1}$ Nor between the last night and the first day has there been or will there be so exalted and so magnificent a procedure, either by one or by the other; for God was more bounteous in giving himself to make man sufficient to raise himself again, than if he solely of himself had remitted ...

2 A. C. Mastrobuono, Dante's Journey of Sanctification (Washington, D.C.: Gateway, 1990), especially Chapter 1 ('Justification and Merit'). C. S. Singleton, Journey to Beatrice (Cambridge, Mass.: Harvard University Press, 1958), cited by Mastrobuono in the 1967 edition from the same press. G. Mazzotta, Dante: Poet of the Desert. History and Allegory in the Divine Comedy (Princeton, N.J.: Princeton University Press, 1979); J. Freccero (relative to whom Mastrobuono's lengthy appendix 'A Book Twenty-Five Years in the Making', pp. 212-79), Dante. The Poetics of Conversion (Cambridge, Mass.: Harvard University Press, 1986). Peter Armour on the merits of Mastrobuono's book as a timely critique of 'the most influential American Dante scholar of recent years' but as 'intemperate' and apt to 'alienate the reader, Modern Language Review 88 (1993) 1, 219-20; similarly Christopher Ryan, Italian Studies 46 (1991), 110-14. 
its preface (page $\mathrm{x}$ ), reproduces the following passage from Singleton to the effect that

what we are finally privileged to see is clear: Dante has continued to work with the metaphor 'return to Eden' even in this respect. At the summit and end of the climb up the mountain, when Eden is reached, we may see history somehow repeating itself; as it was with Adam in his formation, so now with this man, so now with 'man', in his reformation. Only now do we glimpse an aspect of the metaphor we might otherwise have missed. There had been a moment in Adam's formation when Adam was not yet in Eden, when Adam was formed outside of Eden in a first condition 'secundum naturam'. What corresponds to this, in a 'return' to Eden, is the moment when Virgil proclaims that Dante the Wayfarer is now reformed in justice, a justice discernible by the natural light. This then is the moment 'secundum naturam' in the reformation.

The pattern of the original formation of man is thus seen to repeat itself in the reformation of a man named Dante, who attains first to a condition of justice with Virgil, within the proportion of his nature and under the natural light, and then, in a second moment attains to Eden proper, crossing the river to a kind of justice with Beatrice that is truly beyond all human measure.

In fact, Mastrobuono would have done better to quote in full at this point, for occupying the space between what here look like consecutive paragraphs there is, in the original, additional material summing up Singleton's main thesis in the book - namely, his sense of how it is that, having been confirmed under the auspices of Virgil in a state of natural justice, Dante aspires in the earthly paradise, and in the presence of Beatrice, to one of supernatural justice, to a species of righteousness ushered in by grace:

Dante advances to a stream which cuts across his path and blocks his way. He may go no further for the moment, nor may Virgil ever go further than this. Beatrice is expected and when she comes Virgil has disappeared. The light of grace flashes through the forest, from beyond the stream. And when after contrition and confession, Dante may cross through the water to the far shore, to attain to Beatrice and the infused virtues, we know that he crosses to a condition of grace and justice beyond Virgil and beyond nature. And we come to understand better why that further bank of the stream where Beatrice comes is called a 'blessed' shore.

The stream of Lethe in Eden is as a boundary, marking the confines of the Paradise proper. Return to Eden is thus not complete until the wayfarer has crossed over. Only when he stands on the far 
shore, where Beatrice and Matelda are, does he stand in that place where God has placed him after He had formed him outside the Garden, according to nature.

Fully restored, then, the passage offers a faithful account of what, theologically, Singleton thinks is going on in the Commedia. Everything leading up to the gracing of the pilgrim's soul in the Earthly Paradise is, he believes, a preparation for that gracing, a praeparatio ad gratiam accomplished by way of an as yet ungraced movement of the spirit, of the kind of natural reasonableness proper to one such as Virgil. This situation is open to exploration, he thinks, on the basis of the analogy to be drawn between justification and generation, for just as God is said to breathe the rational soul into the sensitive soul generated ex materia, ${ }^{3}$ so also might he be said to grace the natural activity of man as a creature of reasonable moral determination with a view to its ulterior perfection, to its resolution on a higher plane of knowing and loving; so, for example, these lines from page 46 of the Journey to Beatrice, secure in their sense of grace and gracing as a matter of something like formal specification:

This clearly becomes a point of very particular interest to our consideration of the substance and basic structural progression of Dante's poem, when we realize that the whole area of Virgil's guidance in

${ }^{3}$ Purg. XXV.67-75: 'Apri a la verità che viene il petto; / e sappi che, sì tosto come al feto / l'articular del cerebro è perfetto, / lo motor primo a lui si volge lieto / sovra tant'arte di natura, e spira / spirito novo, di vertù repleto, / che ciò che trova attivo quivi, tira / in sua sustanzia, e fassi un'alma sola, / che vive e sente e sé in sé rigira', with a parallel passage in the Convivio at IV.xxi.4: 'E però dico che quando l'umano seme cade nel suo recettaculo, cioè ne la matrice, esso porta seco la vertù de l'anima generativa e la vertù del cielo e la vertù de li elementi legati, cioè la complessione; e matura e dispone la materia a la vertù formativa, la quale diede l'anima del generante; e la vertù formativa prepara li organi a la vertù celestiale, che produce de la potenza del seme l'anima in vita'. G. Di Giannatale, 'Considerazioni sull'origine dell'anima in Dante', Sapienza 30 (1977), 4, 450-54; B. Nardi, 'L'origine dell'anima umana secondo Dante', in Studi di filosofia medievale (Rome: Edizioni di storia e letteratura, 1979; originally 1960), pp. 9-68; idem, 'Sull'origine dell'anima umana', in Dante e la cultura medievale, ed. P. Mazzantini (Bari: Laterza, 1983; originally 1942), pp. 207-24, with 'L'immortalità dell'anima' at pp. 225-43; idem, 'Il canto XXV del Purgatorio', in Lecturae ed altri studidanteschi, ed. R. Abardo with an introduction by F. Mazzoni and A. Vallone (Florence: Le Lettere, 1990), pp. 139-50; S. Bemrose, "Come d'animal divenga fante". The Animation of the Human Embryo in Dante', in The Human Embryo. Aristotle and the Arabic and European Traditions, ed. G. R. Dunstan (Exeter: University of Exeter Press, 1990), pp. 123-35; idem, 'God so Loves the Soul. Intellections of Immortality in Dante', in Medium Aevum 74 (2005), 1, 86-108; M. Gragnolati, Experiencing the Afterlife. Soul and Body in Dante and Medieval Culture (Notre Dame, Ind.: University of Notre Dame Press, 2005), especially Chapter 2 ('Embryology and Aerial Bodies in Dante's Comedy'), pp. 53-87 - much of this discussion turning on the evolutionary character of Dantean psychogenesis over against Thomist substitutionalism. 
the Comedy is that of praeparatio ad gratiam, and that had the Aristotelian notion of generatio not prevailed so generally in the thought of the poet's time, the event of the journey would not have been at all as it is.

If, then, sanctifying grace is 'form' and if the process of conversion is construed on such a pattern of generatio, what exactly are we to understand the 'matter' to be which is made ready to receive that form? The matter is, in the broadest sense, some human creature ...

More exactly, Singleton thinks, it is a question here of grace as that whereby reason and will are 'elevated above the limits of what is natural to man', of what he is able to do from out of his ordinary power to moral selfdetermination. It is by way of grace and its power to 'transhumanization' that he is raised above himself in point of understanding and confirmed in his status as an adopted son of God:

But the advent of Beatrice is not merely the advent of light. By such grace as she (in allegory) is, man's whole nature is transformed, elevated above the limits of what is natural to man. A trasumanar takes place, not in the intellect alone but also in the will. A new orientation of the inner man prevails, itinerarium mentiv 'turns' and moves in a new way. Through sanctifying grace the soul is uplifted and turned toward God as to its special object of beatitude. By such grace alone do we become the 'adopted sons of God'. (ibid., p. 42)

But on both accounts, Mastrobuono maintains, Singleton is mistaken. He is mistaken as regards the analogy to be drawn between justification and generation in that, while the latter is accomplished in the order of time, the former is accomplished in the order of being. Grace as a principle of justification, in other words, functions on the plane, not of the horizontal or of the before and after of the moment, but on that of the vertical or of the height and depth of the instant, successionality thus giving way to simultaneity or all-at-onceness as a means of understanding here; so, for example, this from the Prima secundae at 113.7 resp.:

tota justificatio impii originaliter consistit in gratiae infusione. Per eam enim et liberum arbitrium movetur, et culpa remittitur. Gratiae autem infusio fit in instanti absque successione ... Cum igitur virtus divina sit infinita, potest quamcumque materiam creatam subito disponere ad formam, et multo magis liberum arbitrium hominis, cujus motus potest esse instantaneus secundum naturam. Sic igitur justificatio impii fit a Deo in instanti. ${ }^{4}$

${ }^{4}$ The entire justification of the ungodly consists as to its origin in the infusion of grace. For it is by grace that free will is moved and $\sin$ is remitted. Now the infusion of grace 
But that is not all, for we do not speak of the powers of the soul, but rather of the soul itself, as graced. True, it is by faith as an infused virtue of the intellect and by charity as an infused virtue of the will that man is said to participate in the life of the Godhead, but preceding these things and subsisting as their indispensable condition is the recreative work of grace in the recesses of the soul itself. Thomas again:

... ista quaestio ex praecedenti dependet. Si enim gratia sit idem quod virtus, necesse est quod sit in potentia animae sicut in subiecto; nam potentia animae est proprium subiectum virtutis, ut supra dictum est. Si autem gratia differt a virtute, non potest dici quod potentia animae sit gratiae subiectum; quia omnis perfectio potentiae animae habet rationem virtutis, ut supra dictum est. Unde relinquitur quod gratia, sicut est prius virtute, ita habeat subiectum prius potentiis animae, ita scilicet quod sit in essentia animae. Sicut enim per potentiam intellectivam homo participat cognitionem divinam per virtutem fidei, et secundum potentiam voluntatis amorem divinum per virtutem caritatis; ita etiam per naturam animae participat secundum quamdam similitudinem naturam divinam per quamdam regenerationem, sive recreationem.

$(S T \text { Ia IIae.110.4 resp. })^{5}$

takes place in an instant and without succession ... Therefore, since the divine power is infinite, it can suddenly dispose any matter whatsoever to its form; and much more man's free will, whose movement is by nature instantaneous. Therefore the justification of the ungodly by God takes place in an instant. De verit. 28.9 resp. ult.: 'Dico igitur, quod extrema iustificationis sunt gratia et privatio gratiae, inter quae non cadit medium circa proprium susceptibile: unde oportet quod transitus de uno in alterum sit in instanti, quamvis causa huius privationis successive tollatur; vel secundum quod homo cogitando disponit se ad gratiam, vel saltem secundum quod tempus praeterit postquam Deus se gratiam daturum praeordinavit; et sic gratiae infusio fit in instanti. Et quia expulsio culpae est formalis effectus gratiae infusae, inde est quod tota iustificatio impii in instanti est. Nam forma et dispositio ad formam completam et abiectio alterius formae, totum est in instanti', etc. Mastrobuono, p. 49.

${ }^{5}$ this question depends on the preceding. For if grace is the same as virtue, it must necessarily be in the powers of the soul as in a subject; since the soul's powers are the proper subject of the virtue, as stated above [qu. 56, art. 1]. But if grace differs from virtue, it cannot be said that a power of the soul is the subject of grace, since every perfection of the soul's powers has the nature of virtue, as stated above [qu. 55, art. 1; qu. 56, art. 1]. Hence it remains that grace, as it is prior to virtue, has a subject prior to the powers of the soul, so that it is in the essence of the soul. For as man in his intellective power participates in the divine knowledge through the virtue of faith, and in his power of the will participates in the divine love through the virtue of charity, so also in the nature of the soul does he participate in the divine nature, after the manner of a likeness, through a certain regeneration or re-creation. Mastrobuono, pp. 17-18. 
Grace, then, is present to the individual, not operationally or as empowering reason and will as faculties of the rational soul, but entitatively or as a principle of transformation in respect of the soul in its totality (which is why we speak of it as a matter of accidental or superadditional formality). ${ }^{6}$ And it is this sense in Aquinas of the ontological as distinct from the merely operational character of grace in its positive working out that enables Mastrobuono to reconstruct over against the Singletonians the position in Dante. Grace, he believes, is understood in the Commedia to function both operatively and co-operatively. ${ }^{7}$ It functions co-

${ }^{6}$ Thomas, ST Ia IIae.110.2 ad 1 and ad 2: 'gratia, secundum quod est qualitas, dicitur agere in animam non per modum causae efficientis, sed per modum causae formalis, sicut albedo facit album, et iustitia iustum ... Et quia gratia est supra naturam humanam, non potest esse quod sit substantia aut forma substantialis; sed est forma accidentalis ipsius animae'; $S c G$ III.cl.6: 'Oportet quod homo ad ultimum finem per proprias operationes perveniat. Unumquodque autem operatur secundum propriam formam. Oportet igitur, ad hoc quod homo perducatur in ultimum finem per proprias operationes, quod superaddatur ei aliqua forma, ex qua eius operationes efficaciam aliquam accipiant promerendi ultimum finem', etc.

${ }^{7}$ Cf. Thomas, ST Ia IIae.111.2, resp.: 'Est autem in nobis duplex actus: primus quidem interior voluntatis; et quantum ad istum actum voluntas se habet ut mota, Deus autem ut movens; et praesertim cum voluntas incipit bonum velle, quae prius malum volebat; ei ideo, secundum quod Deus movet humanam mentem ad hunc actum, dicitur gratia operans. Alius autem actus est exterior, qui cum a voluntate imperetur, ut supra habitum est [qu. 17, art. 9], consequens est quod ad hunc actum operatio attribuatur voluntati. Et quia etiam ad hunc actum Deus nos adjuvat, et interius confirmando voluntatem, ut ad actum perveniat, et exterius facultatem operandi praebendo; respectu huiusmodi actus dicitur gratia cooperans. Unde post praemissa verba subdit Augustinus [De gratia et lib. arb. $\mathrm{xvii}$, in the sed contra]: "Ut autem velimus, operatur; cum autem volumus, ut perficiamus, nobis cooperatur"' (Augustine, in the De gratia et lib. arb. xvii.33, has the following: 'Et quis istam etsi parvam dare coeperat caritatem, nisi ille qui praeparat voluntatem, et cooperando perficit, quod operando incipit? Quoniam ipse ut velimus operatur incipiens, qui volentibus cooperatur perficiens. Propter quod ait Apostolus: "Certus sum quoniam qui operatur in vobis opus bonum, perficiet usque in diem Christi Iesu" [Philip. 1:6]. Ut ergo velimus, sine nobis operatur; cum autem volumus, et sic volumus ut faciamus, nobiscum cooperatur; tamen sine illo vel operante ut velimus, vel cooperante cum volumus, ad bona pietatis opeera nihil valemus. De operante illo ut velimus, dictum est: "Deus est enim qui operatur in vobis et velle" [Philip. 2:13]. De cooperante autem cum iam volumus et volendo facimus: "Scimus", inquit, "quoniam diligentibus Deum omnia cooperatur in bonum” [Rom. 8:28]'); Bonaventure, II Sent. d. 5, c. 4: 'Operans quidem gratia dicitur, qua iustificatur impius, id est de impio fuit pius, de malo bonus. Cooperans vero, qua iuvatur ad bene volendum efficaciter et Deum prae omnibus diligendum et ad operandum bonum et ad perseverandum in bono et huiusmodi', etc. R. GarrigouLagrange, O.P., La Prédestination des saints et la grâce: Joctrine de Saint Thomas comparée aux autres systèmes théologiques (Paris: Desclée de Brouwer, 1936); idem, Grace: Commentary on the Summa Theologica of St Thomas, Ia IIae, 109-14, trans. from the Commentarius of 1947 (Rome: Pontificium Institutum Internationale 'Angelicum') by the Dominican Nuns of the Corpus Christi Monastery, Menlo Park, California (St. Louis: B. Herder, 1952); B. 
operatively in that it is everywhere on hand, in circumstances at any rate of justification, to assist and strengthen the individual in his commitment to right being and right doing, to living out the substance of his nature as a creature of moral and ontological accountability. But first comes the moment of justification, the moment in which, quickened by grace under the aspect of operation, the soul is (a) turned away from self towards God, (b) deflected from its old habits, and (c) absolved from its sin, these between them constituting the basis of everything coming next by way either of infused or of acquired virtue. ${ }^{8}$ This, then, Mastrobuono maintains, is where Dante begins. Having reconstructed in the person of his protagonist the substance and psychology of estrangement from self and from the innermost reasons of self, he begins with the grace proclaimed by Virgil in the second canto of the Inferno whereby the soul is duly disposed towards God (the 'Tu m'hai con desiderio il cor disposto' of II.136) and quickened afresh in point of willing (the 'Or va, ch'un sol volere

J. F. Lonergan, S.J., 'St Thomas's Thought on Gratia Operans', Theological Studies 2 (1941), 3, 289-324; 3 (1942), 1, 69-88; 3, 375-402 and 4. 533-78; idem, Grace and Freedom: Operative Grace in the Thought of St Thomas Aquinas, ed. F. E. Crowe and R. M. Doran (Toronto: University of Toronto Press, 2000; originally 1971); H. Bouillard, Conversion et grâce chez d. Thomas J'Aquin: étude bistorique (Paris: Aubier, 1944); M. Flick, L'attimo della giustificazione secondo S. Tommaso (Rome: Apud aedes Universitatis Gregorianiae, 1947); P. Wehbrink (trans), Thomas von Aquin. Die menschliche Willensfreibeit (Düsseldorf: L. Schwann, 1954; selections from the Quaestiones disputatae de malo and de veritate with an introduction by G. Siewerth); C. Ernst, O.P. (ed. and comm.), St Thomas Aquinas. Summa theologiae, vol. 30 (The Gospel of Grace. 1a 2a. 106-114) (London: Eyre and Spottiswoode, 1972); J. P. Wawrykow, God's Grace and Human Action. 'Merit' in the Theology of Thomas Aquinas (Notre Dame: University of Notre Dame Press, 1995); idem, 'Grace', in The Theology of Thomas Aquinas, ed. R. Van Nieuwenhove and J. Wawrykow (Notre Dame: University of Notre Dame Press, 2005), pp. 192-221; J. F. Wippel, 'Natur und Gnade (S.th. I-II, qq. 109114)', in Thomas von Aquin: Die Summa theologiae. Werkinterpretationen, ed. A. Speer (Berlin: de Gruyter, 2005), pp. 246-70. More generally on grace theology (but with reference still to Thomas), J. Auer, Die Entwicklung der Gnadenlebre in Jer Hochscholastik, 2 vols (Freiburg: Herder, 1951); R. W. Gleason, S.J., Grace (London and New York: Sheed and Ward, 1962); N. P. Williams, The Grace of God (London: Hodder and Stoughton, 1966, originally 1930).

${ }^{8}$ Thomas, ST Ia IIae.113.6 resp.: 'quatuor enumerantur quae requiruntur ad iustificationem impii, scilicet gratiae infusio; motus liberi arbitrii in Deum per fidem; et motus liberi arbitrii in peccatum; et remissio culpae. Cuius ratio est quia, sicut dictum est, iustificatio est quidam motus quo anima movetur a Deo a statu culpae in statum iustitiae. In quolibet autem motu quo aliquid ab altero movetur, tria requiruntur, primo quidem, motio ipsius moventis; secundo, motus mobilis; et tertio, consummatio motus, sive perventio ad finem. Ex parte igitur motionis divinae, accipitur gratiae infusio; ex parte vero liberi arbitrii moti, accipiuntur duo motus ipsius, secundum recessum a termino a quo, et accessum ad terminum ad quem; consummatio autem, sive perventio ad terminum huius motus, importatur per remissionem culpae, in hoc enim iustificatio consummatur.' 
è d'ambedue' of II.139). ${ }^{9}$ Grace, then, far from intervening subsequently to perfect the hitherto ungraced work of nature, is there from the outset as both the antecedent and the subsistent principle of man's proper striving as man, of every creative inflexion of the spirit on the plane of properly human being and becoming:

All of this, according to Singleton, is within the proportion of Dante's nature to accomplish, aided, of course, by Virgil's natural light of reason ... Singleton does not seem to understand that the natural reason symbolized by Virgil is an immanent power, and as such is absolutely impotent to erase the effects of sin from Dante's soul. For this, Dante needs the transcendent power of grace. Since it does in fact happen that on the mountain of Purgatory the effects of sin (the stains) are erased from Dante's soul, as the 'P's are erased from his forehead, that in itself is proof, as we have noted, that Dante has already received an infusion of sanctifying grace before he entered the world beyond. The erasing of the effects of sin from Dante's soul is an effect of sanctifying grace, not a preparation for it, which also means that the whole area of Virgil's guidance through the world beyond is an effect of sanctifying grace, not a preparation for it as Singleton also believes. ${ }^{10}$

Dante's, in other words, though at every point a sense both of the power in man to moral self-determination and of this as the ground of his eschatological triumph and tragedy, is at the same time a commitment to the priority of grace as the condition of his righteousness, of the individual's knowing himself in the fullness and functionality of his proper humanity. To suppose otherwise - to imagine that, for the Dante of the Commedia, it is a question of the periodization of these things, of what comes next in the order of time - is to implicate him in a species of theological absurdity.

2. Dante's, for all his commitment to the notion of grace as incomingness, is a tendency to see and to celebrate it under the aspect of alongsidedness, and indeed of a species of alongsidedness amounting in its intimacy to something closer to co-immanence, to a commingling of human and divine intentionality at the still centre of existence; ${ }^{11}$ so, for example, as

${ }^{9}$ By your words you have made me so eager [to come with you that I have returned to my first resolve] ... Now on, for a single will is in us both ...

${ }^{10}$ Mastrobuono, p. 59.

${ }^{11}$ Recently on Dante and grace: S. Rossi, 'Il trionfo della grazia nell'episodio di Bonconte da Montefeltro', L'Alighieri. Rassegna bibliografica Jantesca 35, n.s. 3/4 (1994), 83-93; C. Ryan, “Natura dividitur contra gratiam”: concetti diversi della natura in Dante e nella cultura filosofico-teologica medievale', in Dante e la scienza. Attidel Convegno 
eloquent in respect of the first of these things, of incomingness under the aspect of alongsidedness, these passages from Cantos XXV, XXVIII and XXIX of the Paradiso, each of them turning on the parallelization as distinct from the prioritization of grace with respect to nature in the moment of its verification:

"Spene", diss' io, "è uno attender certo de la gloria futura, il qual produce grazia divina e precedente merto". ...

Quinci si può veder come si fonda l'esser beato ne l'atto che vede, non in quel ch'ama, che poscia seconda;

e del vedere è misura mercede, che grazia partorisce e buona voglia ...

per che le viste lor furo essaltate con grazia illuminante e con lor merto, si c'hanno ferma e piena volontate.

(Par. XXV.67-69, XXVIII.109-13 and XXIX.61-63) ${ }^{12}$

Internazionale di Studi, Ravenna 28-30 maggio 1993, ed. P. Boyde and V. Russo (Ravenna: Longo, 1995), pp. 363-73; L. Scorrano, 'Paradiso XXXII. La legge, la grazia', LiAlighieri. Rassegna bibliografica Jantesca 37, n.s. 7 (1996), 19-36, subsequently in Tra il 'banco' e 'l'alte rote'. Letture e note Jantesche (Ravenna: Longo, 1996), pp. 103-22; I. Biffi, La poesia e la grazia nella Commedia di Dante (Milan: Jaca Book, 1999), especially pp. 29. 35 ('Un viaggio che parte dalla grazia'); J. T. Chiampi, 'The role of freely bestowed grace in Dante's journey of legitimation', in Rivista di Studi Italiani 17 (1999), 1, 89-111; J. Trabant, “Gloria” oder "grazia”. Oder: Wonach die "questione della lingua" eigentlich fragt', Romanistisches Jabrbuch 51 (2000), 29-52; P. Cherchi, 'Da me stesso non vegno (Inf. X, 61)', Rassegna europea di letteratura italiana 18 (2001), 103-106. Notable prior to Mastrobuono are G. Getto, 'L'epos” della grazia in Paradiso', in Scrittori e idee in Italia: Antologia della critica. (Dalle Origini al Trecento), ed. P. Pullega (Bologna: Zanichelli, 1982), pp. 209-14; G. Godenzi, 'Il viaggio spirituale di Dante dal peccato alla grazia', in Quaderni Grigionitaliani. Rivista trimestrale delle valli Grigionitaliane 56 (1987), 3-4, 23439; B. Panvini, 'La concezione tomistica della grazia nella Divina Commedia', in Letture classensi 17 (Ravenna: Longo, 1988), pp. 69-85.

12 "Hope", I said, "is a sure expectation of future glory, which divine grace produces, and preceding merit" ... From this it may be seen that the state of blessedness is founded on the act of vision, not on that which loves, which follows after; and the merit, to which grace and good will give birth, is the measure of their vision ... wherefore their vision was exalted with illuminating grace and with their merit, so that they have their will full and established. Peter Lombard's text to the effect that 'est autem spes virtus qua spiritualia et aeterna bona sperantur, id est cum fiducia expectantur. Est enim certa expectatio futurae beatitudinis, veniens ex Dei gratia et ex meritis praecedentibus vel ipsam spem, quam natura praeit caritas; vel rem speratam, id est beatitudinem aeternam' (III Sent. xxvi), though variously cited by Thomas, is glossed, at any rate in the Secunda secundae 
while exemplary in respect of the second of them, of the resolution of alongsidedness in co-immanence, in a 'commingling of human and divine intentionality at the still centre of existence', these lines from the Piccarda canto of the Paradiso, explicit in their sense of willing in man as a matter of in-willing, of a reconfiguration of human willing by way of an in-breathing of divine willing in the recesses of personality:

Frate, la nostra volontà quïeta

virtù di carità, che fa volerne sol quel ch'avemo, e d'altro non ci asseta.

Se disïassimo esser più superne, foran discordi li nostri disiri dal voler di colui che qui ne cerne;

che vedrai non capere in questi giri, s'essere in carità è qui necesse, e se la sua natura ben rimiri.

Anzi è formale ad esto beato esse tenersi dentro a la divina voglia, per ch'una fansi nostre voglie stesse;

sì che, come noi sem di soglia in soglia per questo regno, a tutto il regno piace com' a lo re che 'n suo voler ne 'nvoglia.

E'n la sua volontade è nostra pace: ell' è quel mare al qual tutto si move ciò ch'ella crïa o che natura face.

(17.1 ad 2), in such a way as to stress the notion of hope as an infused virtue of the spirit and thus as radically independent of merit: 'spes dicitur ex meritis provenire quantum ad ipsam rem expectatam, prout aliquis sperat se beatitudinem adepturum ex gratia et meritis. Vel quantum ad actum spei formatae. Ipse autem habitus spei, per quam aliquis expectat beatitudinem, non causatur ex meritis, sed pure ex gratia.' J.-G. Bougerol, La Théologie de l'espérance aux XIIe et XIIIe siècles, 2 vols (Paris: Etudes augustiniennes, 1985), vol. 1, pp. 97-99. Otherwise on Peter Lombard and the Sentences (in addition to the general histories of medieval thought), M. L. Colish, Peter Lombard, 2 vols (Leiden and New York: Brill, 1994); J.-G. Bougerol, 'The Church Fathers and the Sentences of Peter Lombard', in I. Backus (ed.), The Reception of the Church Fathers in the West from the Carolingians to the Maurists, 2 vols (Leiden and New York: Brill, 1997; also Boston: Brill Academic Publishers, 2001), vol. 1, pp. 113-64. On Dante and Peter Lombard, M. Papio, ad voc. 'Peter Lombard' in R. Lansing (ed.), Dante Encyclopaedia (London: Garland, 2000), pp. 682-83, with bibliography. Also, M. Da Carbonara, Dante e Pier Lombardo ; Sent, lib. IV, Jistt. $43-49$ (Città di Castello: Lapi, 1897).

13 Brother, the power of love quiets our will and makes us wish only for that which we have and gives us no other thirst. Did we desire to be more aloft, our longings would be discordant with his will who assigns us here, which you will see is not possible in these circles if to exist in charity here is of necessity, and if you well consider what is love's 
Now here, clearly, we have to be careful, for grace, for all its subsisting as a matter of alongsidedness and indeed of co-immanence in respect of the power in man to significant determination, subsists also both as an antecedent and as an extrinsic principle of new life, as a principle, that is to say, operative both from beforehand and from beyond. But for all that, Dante's, when it comes to a question famous for its distribution and redistribution of emphases, remains a tendency to proceed by way, less of antecedence and exteriority than of simultaneity and companionship, of what for the sake of capturing the intensity - not to mention the beauty of it we may call a species of formed friendship. No longer, in other words, is it a question of grace as a stranger to nature, as visited upon it in all its otherwise unspeakable poverty, but of a welcoming home of the one by the other in the deepest and most sacred places of historical selfhood. And it is this resolution of the antecedent in the alongsided as a way of proposing the grace-theological issue in the moment of its positive living out that inclines Dante, less to a metaphysic, than to a phenomenology of grace, to an account of grace and of gracing in terms, less of its mechanism, than of its modality, of the how of its experiencing as a principle of self-actualization.

3. Grace, then, as a matter of its how or showing forth, not only abounds, but abounds in every sector of human experience in the living out of that experience. Thus it is by grace that the penitent soul knows itself in the free passage from seeing and understanding to being and doing (the 'se tosto grazia resolva le schiume / di vostra coscienza sì che chiaro / per essa scenda de la mente il fiume' of Purg. XIII.88-90), ${ }^{14}$ and it is by

nature. Indeed, it is of the essence of this blessed existence to keep itself within the divine will, whereby our wills are made one; so that our being thus from threshold to threshold throughout this realm is a joy to all the realm as to the king, who inwills us with his will; and in his will is our peace. It is that sea to which all moves, both what it creates and what nature makes.

${ }^{14}$ so may grace soon clear the scum of your conscience that the stream of memory may flow down through it pure ... On synderesis and conscience, O. Lottin, "Syndérèse" et conscience au XIIe et XIIIe siècles', in Psychologie et morale aux XIIe et XIIIe siècles (Louvain: Abbaye du Mont César, 1948), vol. 2, pp. 103-349; P. Siwek, La conscience du libre arbitre (Rome: Herder, 1976); M. G. Baylor, Action and Person: Conscience in Late Scholasticism and the Young Luther (Leiden: Brill, 1977); T. Potts, Conscience in Medieval Philosophy (Cambridge: Cambridge University Press, 1980); idem, 'Conscience', in The Cambridge History of Later Medieval Philosophy (Cambridge: Cambridge University Press, 1982), pp. 687-704. On Thomas, L. Elders, 'La doctrine de la conscience de saint Thomas d'Aquin', Revue Thomiste 83 (1983), 533-57; O. Benetollo, 'Il problema della formazione della coscienza retta', Divus Thomas 95 (1992), 113-28; G. Cavalcoli, 'Il concetto di coscienza in s. Tommaso', Divus Thomas 95 (1992), 53-77. More generally on the notion of synderesis, and in addition to Lottin above, J. de Blic, 'Syndérèse ou conscience?', Revue J'ascétique et de mystique 25 (1949), 146-57; M. B. Crowe, 'The Term Synderesis in 
grace that it knows itself in its equality to every kind of intemperance and extravagance of the spirit (the 'Beati cui alluma / tanto di grazia, che l'amor del gusto / nel petto lor troppo disir non fuma' of Purg. XXIV.15153). ${ }^{15} \mathrm{It}$ is by grace that it knows itself as encircled by the love of God (the 'se Dio m'ha in sua grazia rinchiuso' of Purg. XVI.40), ${ }^{16}$ and it is by grace that it knows itself in the exhilaration of self-surpassing on the planes of knowing and of loving (the 'Ringrazia, / ringrazia il Sol de li angeli, ch'a questo / sensibil t'ha levato per sua grazia' of Par. X.52-54 and the 'Con tutto 'l core e con quella favella / ch'è una in tutti, a Dio feci olocausto, / qual conveniesi a la grazia novella' of Par. XIV.88-90). ${ }^{17}$ It is by grace, moreover, that the mind is caressed by the truth to which it is now party (the 'Grazia, che donnea / con la tua mente' of Par. XXIV.11819), ${ }^{18}$ and it is by grace that the individual knows himself in the bliss of spiritual sonship (the 'Figliuol di grazia' of Par. XXXI.112). Grace, then, is everywhere present to the individual as the context and co-efficient of his every creative inflexion of the spirit, Dante's in this sense being a never less than fervent commitment to its status both as an immanent and as an overarching principle of human experience in its historical

the Scholastics', The Irish Theological Quarterly 23 (1956), 151-64 and 228-45; T. L. Miethe, 'Natural Law, the Synderesis Rule, and St Augustine', Augustinian Studies 11 (1980), 9197; V. J. Bourke, 'The Background of Aquinas's Synderesis Principle', in Graceful Reason. Essays in Ancient and Medieval Philosophy presented to James Owens, ed. L. P. Gerson (Toronto: Pontifical Institute of Mediaeval Studies, 1983), pp. 345-60; R. A. Greene, 'Synderesis, the Spark of Conscience, in the English Renaissance', Journal of the History of Ideas 52 (1991), 2, 195-219; idem, 'Instinct of Nature. Natural Law, Synderesis and Moral Sense', Journal of the History of Ideas 58 (1997), 173-98; I. Sciuto, 'Sinderesi, desiderio naturale e fondamento dell'agire morale nel pensiero medievale. Da San Tommaso a Meister Eckhart', in L'etica eil suo altro, ed. C. Vigna (Milan: Vita e pensiero, 1994); idem, La felicità e il male. Studidi etica medievale (Milan: Franco Angeli, 1995). Dante on conscience as a principle of interrogation and affirmation, Inf. XV.91-93 and (especially) XXVIII.112-17, and as a principle of remorse or 'biting back', Inf. XIX.118-20, Purg. III.7-9, XIX.131-32 and XXXIII. 91-93 (cf. Augustine, Serm. de script. XLVII.xiv.23: 'Forte alius conscientia mordetur, alius in conscientiae, tanquam in eremo, requiescit'; Serm. de temp. ccxi.3: 'Si autem mordet conscientia fragilitatis ..., etc.).

${ }^{15}$ Blessed are they who are so illumined by grace that the love of taste kindles not too great a desire in their breasts, and who hunger always so far as is just.

${ }^{16}$ and since God has received me so far into his grace [that he wills that I see his court in a manner wholly outside modern usage, do not hide from me who you were before death ...]

17 Give thanks, give thanks to the sun of the angels who of his grace has raised you to this visible one ... with all my heart, and with that speech which is one in all men, I made a holocaust to God such as befitted the new grace.

18 the grace that holds amorous discourse with your mind [till now has opened your lips aright, so that I approve what has come from them]. 
unfolding. But it is under three aspects in particular that, for the Dante of the Commedia, grace is most powerfully present to the one graced, namely as a principle (a) of encouragement or as that whereby the soul knows itself in its power to moral and ontological self-confrontation (the infernal phase of its journey into God); (b) of emancipation or as that whereby it knows itself in its power to affective self-reconfiguration (the purgatorial phase of the journey); and (c) of ecstasy or as that whereby it knows itself in its power to self-transcendence (the paradisal phase of the journey). Now this, as we have said, is by no means to exclude the many other ways in which grace is experienced by the pilgrim spirit, for the ways and means of grace are as infinite and infinitely varied as the One from whom it proceeds. But it is under these three aspects especially - under the aspects of encouragement, emancipation and ecstasis as between them facilitating and confirming this or that instance of properly human being in the world - that grace as but the overflowing of the Godhead in ever fresh channels of creative and recreative concern commends itself to Dante as an object of contemplation.

Grace is present to those graced as a principle of encouragement in that, irrespective of every thing within the economy of personality making for fear as the dominant mood of being under the conditions of time and space, the soul reaches out to affirm itself in the fullness of its proper humanity. Straightaway, then, it is a question in the Inferno of doubt and energization, of an empowerment of the crippled spirit in and through a movement of grace mediated by Virgil; on the one hand, these lines (37-42) from Inferno II on the demonic character not, certainly, of pure thought as such, but of pure thought in its endless capacity for reiteration, for staving off the moment of decision:

E qual è quei che disvuol ciò che volle e per novi pensier cangia proposta, sì che dal cominciar tutto si tolle,

tal mi fec' io 'n quella oscura costa, perché, pensando, consumai la 'mpresa che fu nel cominciar cotanto tosta. ${ }^{19}$

${ }_{19}$ And like one who unwills what he has willed and with new thoughts changes his resolve, so that he quite gives up the thing he had begun, such did I become on that dark slope, for by thinking on it I rendered null the undertaking that had been so readily embarked on. Cf. Purg. V.13-18: 'Vien dietro a me, e lascia dir le genti: / sta come torre ferma, che non crolla / già mai la cima per soffiar di venti; / ché sempre l'omo in cui pensier rampolla / sovra pensier, da sé dilunga il segno, / perché la foga l'un de l'altro insolla.' On the gnawing of reflection and the issuelessness of pure thought, Søren Kierkegaard, The Present Age, trans. A Dru (London: Collins, 1962), p. 45: 'ambiguity enters into life when the qualitative distinctions are weakened by a gnawing reflection'; ibid., p. 52: 'With every means in its 
while on the other these from the same canto (lines 121-42) on the revitalization of self by way of a movement of grace as solicitude from on high:

"Dunque: che è? perché, perché restai?

perché tanta viltà nel core allette?

perché ardire e franchezza non hai?

poscia che tai tre donne benedette

curan di te ne la corte del cielo,

e 'l mio parlar tanto ben ti promette?".

Quali fioretti dal notturno gelo

chinati e chiusi, poi che 'l sol li 'mbianca

si drizzan tutti aperti in loro stelo,

tal mi fec' io di mia virtude stanca,

e tanto buono ardire al cor mi corse,

ch'i' cominciai come persona franca:

"Oh pietosa colei che mi soccorse!

e te cortese ch'ubidisti tosto

a le vere parole che ti porse!

Tu m'hai con disiderio il cor disposto

sì al venir con le parole tue,

ch'i' son tornato nel primo proposto.

Or va, ch'un sol volere è d'ambedue:

tu duca, tu segnore, e tu maestro".

Così li dissi; e poi che mosso fue,

intrai per lo cammino alto e silvestro.

(Inf. II.121-42) $)^{20}$

power reflection prevents people from realizing that both the individual and the age are thus imprisoned, not imprisoned by tyrants or priests or nobles or the secret police, but by reflection itself, and it does so by maintaining the flattering and conceited notion that the possibility of reflection is far superior to a mere decision'; Karl Jaspers, Pbilosophy, trans. E. B. Ashton (Chicago: University of Chicago Press, 1970, originally 1932), vol. 2, p. 37, has the following: 'This is the way of succombing to self-reflection without coming to myself. My honesty does not go beyond a will to have clarity; a will which does not amount to selfbeing. This will as such does not affect my future, does not make me hazard any realization. Under its absolute sway I would avoid the risks involved in every manifestation of myself. I would like to know what is true, then, before trying it. I no sooner set out to be real than self-reflection will cast doubt upon my start and destroy it. I cannot take a step any more; I have been paralyzed by my will to be clear.'

20 "Why, why do you hold back? Why do you harbour such cowardice in your heart? Why are you not bold and free, when in heaven's court three such blessed ladies are mindful of you, and my words pledge you so great a good?” As little flowers, bent down and closed by chill of night, straighten and all unfold on their stems when the sun brightens them, such in my faint strength did I become; and so much good courage rushed to my heart that I began, as one set free, "Oh, how compassionate was she who 
Now for Mastrobuono these lines are in the highest degree significant, for it is here, he believes that, on the threshold of a discourse turning on death and resurrection as the way of emergence, Dante, taking his cue from Thomas, sets out his theology of justification, his sense of grace (a) as a matter of preliminary disposition, and (b) as that whereby, as part of its justification, the soul is renewed in point of willing; and the parallel is indeed tempting, the 'Tu m'hai con disiderio il cor disposto' of line 136 chiming well with the 'Primo igitur modo accipiendo gratiam, praeexigitur ad gratiam aliqua gratiae praeparatio; quia nulla forma potest esse nisi in materia disposita' of $S T$ Ia IIae.112.2 resp., ${ }^{21}$ and the 'Or va, ch'un sol volere è d'ambedue' of line 139 with the 'non fit motio a Deo ad iustitiam absque motu liberi arbitrii; sed ita infundit donum gratiae iustificantis, quod etiam simul cum hoc movet liberum arbitrium ad donum gratiae acceptandum, in his qui sunt huius motionis capaces' of Ia IIae.113.3 resp. ${ }^{22}$ But this, for all its suggestion of Dante's taking up and acquiescing in the Thomist text, is not what he has in mind here; for his is an essay, not so much in the theology of justification, in the complex process whereby the soul in receipt of grace eschews sin, espouses God, and is absolved from its guilt, ${ }^{23}$ as in the kind of existential courage whereby the individual commits himself to the business of selfactualization by way of an encounter with self in the depths. Quickened, then, by the grace-proclamation of Virgil and by all this means by way of a movement of divine solicitude, the soul squares up to the necessities of its presence in the world as a creature of eschatological accountability, this,

helped me, and how courteous were you, so quick to obey the true words she spoke to you! By your words you have made me so eager to come with you, that I have returned to my first resolve. Now on, for a single will is in us both; you are my leader and my teacher". So I said to him, and when he moved on, I entered along the deep and savage way.

${ }^{21}$ Now taking grace in the first sense, a certain preparation of grace is required for it, since a form can only be in disposed matter.

${ }^{22}$ God's motion to justice does not take place without a movement of free will; but he so infuses the gift of justifying grace that at the same time he moves the free will to accept the gift of grace, in such as are capable of being moved thus.

${ }^{23}$ ST Ia IIae.113.6 resp.: 'quatuor enumerantur quae requiruntur ad iustificationem impii, scilicet gratiae infusio; motus liberi arbitrii in Deum per fidem; et motus liberi arbitrii in peccatum; et remissio culpae. Cuius ratio est quia, sicut dictum est, iustificatio est quidam motus quo anima movetur a Deo a statu culpae in statum iustitiae. In quolibet autem motu quo aliquid ab altero movetur, tria requiruntur, primo quidem, motio ipsius moventis; secundo, motus mobilis; et tertio, consummatio motus, sive perventio ad finem. Ex parte igitur motionis divinae, accipitur gratiae infusio; ex parte vero liberi arbitrii moti, accipiuntur duo motus ipsius, secundum recessum a termino a quo, et accessum ad terminum ad quem; consummatio autem, sive perventio ad terminum huius motus, importatur per remissionem culpae, in hoc enim iustificatio consummatur.' 
therefore, being the first great work of grace in its positive verification. The first work of grace in its positive verification is the in-breathing of courage, the courage whereby the soul in the grip of ontological dread feels able to contemplate the risk of losing all for the sake of finding all, of essaying death in the interests of life.

But the grace whereby the individual squares up to the necessities of his presence in the world as a creature of eschatological accountability is at the same time the grace whereby he knows himself in the truth of his moral and ontological freedom, in the freedom to affirm self over against everything within the economy of personality making less for being than for non-being. Having, then, taken on board the possibility of losing all for the sake of finding all, the soul encouraged in respect of its proper destiny embarks on the search for freedom thus understood, trusting as it does so to the grace whereby that freedom becomes a possibility. This then, as far as the Purgatorio is concerned, is where Dante starts. Looking now to emancipation as the leading idea, he starts with a referral of the whole project to a movement of grace from above:

Questi non vide mai l'ultima sera; ma per la sua follia le fu sì presso, che molto poco tempo a volger era.

Sì com' io dissi, fui mandato ad esso per lui campare; e non lì era altra via che questa per la quale i' mi son messo.

Mostrata ho lui tutta la gente ria; e ora intendo mostrar quelli spirti che purgan sé sotto la tua balìa.

Com' io l'ho tratto, saria lungo a dirti; de l'alto scende virtù che m'aiuta conducerlo a vederti e a udirti.

Or ti piaccia gradir la sua venuta: libertà va cercando, ch'è sì cara, come sa chi per lei vita rifiuta.

(Purg. I.58-72) $)^{24}$

${ }^{24}$ This man has not seen his last evening, but by his folly was so near to it that very little time was left to run. Even as I said, I was sent to him to rescue him, and there was no other way than this along which I have set myself. I have shown him all the guilty people, and now I intend to show him those spirits that purge themselves under your charge. How I have brought him would be long to tell you; for on high descends the power that aids me to conduct him to see you and to hear you. Now may it please you to approve his coming. He goes seeking freedom, which is so precious, as he knows who renounces life for it. 
And what, as far as the Purgatorio is concerned, is begun in grace is consummated in grace, this being the substance of Dante's final hymn to Beatrice as the means of his emergence as a free spirit:

O donna in cui la mia speranza vige, e che soffristi per la mia salute in inferno lasciar le tue vestige, di tante cose quant' i' ho vedute, dal tuo podere e da la tua bontate riconosco la grazia e la virtute.

Tu m'hai di servo tratto a libertate per tutte quelle vie, per tutt' i modi che di ciò fare avei la potestate.

La tua magnificenza in me custodi, sì che l'anima mia, che fatt' hai sana, piacente a te dal corpo si disnodi.

(Par. XXXI.79-90) $)^{25}$

These certainly, are passages fraught with every kind of theological possibility, not least in respect of the basis they offer for what nowadays we would call a theology of culture, a theology turning on the function of the cultural encounter generally - of, in effect, the Virgilian and Beatrician presence in the life of every man - as a channel of grace in its own right. But that for the moment is neither here nor there, what matters at present being the notion of grace as a principle of emancipation, as that whereby self is freed for self in the untrammeled substance of self. This, then, is the second great work of grace in its positive verification. The second great work of grace in its positive verification is the freeing of the soul for communion with God as the end of all desiring, for the kind of service which is but perfect freedom. ${ }^{26}$

${ }^{25}$ O lady, in whom my hope is strong, and who for my salvation did endure to leave in hell your footprints, of all those things which I have seen I acknowledge the grace and the virtue to be from your power and your excellence. It is you who have drawn me from bondage into liberty by all those paths, by all those means by which you had the power so to do. Preserve me in your great munificence, so that my soul, which you have made whole, may be loosed from the body, pleasing unto you.

${ }^{26}$ Purg. XVI.73-81: 'Lo cielo i vostri movimenti inizia; / non dico tutti, ma, posto ch'i' 'l dica, / lume v'è dato a bene e a malizia, / e libero voler; che, se fatica / ne le prime battaglie col ciel dura, / poi vince tutto, se ben si notrica. / A maggior forza e a miglior natura / liberi soggiacete; e quella cria / la mente in voi, che 'l ciel non ha in sua cura.' E. Travi, “'Liberi soggiacete” (Purg. XVI. 80)', in Dal cerchio al centro (1990), pp. 25-33; M. Roddewig, 'Purgatoio XVI - Zorn und Willensfreiheit', Deutsches Dante-Jabrbuch 74 (1999), 123-35; L. Pretto, 'La ricerca e il senso della libertà nella Divina Commedia', in Con Dante e Cusano alla ricerca della verità (Verona: Mazziana, 2005), pp. 111-39. 
But there is more, for the grace whereby the soul is encouraged in respect of the journey ahead and the grace whereby it is sustained in its search for freedom, is also the grace whereby it projects itself upon its proper ecstasis or self-surpassing on the planes of knowing and loving, upon its proper transhumanization. Now here again we need to be careful, for inasmuch as he chooses to stress the atemporality of the ascent, its accomplishment in the order, less of time, than of being, Dante's looks after all to be a theology of created grace, a theology turning upon the notion of entitative renewal; so for example, these lines (22-26) from Canto II of the Paradiso:

Beatrice in suso, e io in lei guardava;

e forse in tanto in quanto un quadrel posa

e vola e da la noce si dischiava, giunto mi vidi ove mirabil cosa mi torse il viso a sé ...27 or these (lines 91-93) from Canto V:

$\mathrm{e}$ sì come saetta che nel segno percuote pria che sia la corda queta, così corremmo nel secondo regno. ${ }^{28}$

or these (lines 34-39) from Canto X:

e io era con lui; ma del salire non m'accors' io, se non com' uom s'accorge, anzi 'l primo pensier, del suo venire.

È Beatrice quella che sì scorge di bene in meglio, sì subitamente che l'atto suo per tempo non si sporge. ${ }^{29}$

or these (lines 97-105) from Canto XXII:

Così mi disse, e indi si raccolse al suo collegio, e 'l collegio si strinse; poi, come turbo, in sù tutto s'avvolse.

La dolce donna dietro a lor mi pinse

${ }^{27}$ Beatrice was gazing upward, and I on her; and perhaps in that time that a bolt strikes, flies, and from the catch is released, I saw myself arrived where a wondrous thing drew my sight to it ...

${ }^{28}$ and as an arrow that strikes the target before the bowcord is quiet, so we sped into the second realm.

${ }^{29}$ and I was with him, but of my ascent I was no more aware than is a man, before his first thought, aware of its coming. It is Beatrice who thus conducts from good to better, and so swiftly that her act does not extend through time. 
con un sol cenno su per quella scala, sì sua virtù la mia natura vinse;

né mai qua giù dove si monta e cala

naturalmente, fu sì ratto moto

ch'agguagliar si potesse a la mia ala. ${ }^{30}$

- passages nothing if not secure in their sense of the momentary character of the soul's movement into God, of the a-successionality of it all. ${ }^{31}$ But the

${ }^{30}$ Thus he spoke to me, then drew back to his company, and the company closed together; then like a whirlwind all were gathered upward. My sweet lady, with only a sign, thrust me up after them by that ladder, so did her power overcome my nature; nor ever here below, where we mount and descend by nature's law, was motion so swift as might match my flight.

${ }^{31}$ So too VIII.13-15, XIV.79-84 and XXVII.88-99: 'Io non m'accorsi del salire in ella; / ma d'esservi entro mi fé assai fede / la donna mia ch'i' vidi far più bella ... Ma Bëatrice sì bella e ridente / mi si mostrò, che tra quelle vedute / si vuol lasciar che non seguir la mente / Quindi ripreser li occhi miei virtute / a rilevarsi; e vidimi translato / sol con mia donna in più alta salute ... E la virtù che lo sguardo m'indulse, / del bel nido di Leda mi divelse, / e nel ciel velocissimo m'impulse ... La mente innamorata, che donnea / con la mia donna sempre, di ridure / ad essa li occhi più che mai ardea; / e se natura o arte fé pasture / da pigliare occhi, per aver la mente, / in carne umana o ne le sue pitture, / tutte adunate, parrebber nïente / ver' lo piacer divin che mi refulse, / quando mi volsi al suo viso ridente. / E la virtù che lo sguardo m'indulse, / del bel nido di Leda mi divelse, / e nel ciel velocissimo m'impulse.' Thomas, ST Ia IIae.113.7 resp.: 'tota iustificatio impii originaliter consistit in gratiae infusione, per eam enim et liberum arbitrium movetur, et culpa remittitur. Gratiae autem infusio fit in instanti absque successione. Cuius ratio est quia quod aliqua forma non subito imprimatur subiecto, contingit ex hoc quod subiectum non est dispositum, et agens indiget tempore ad hoc quod subiectum disponat. Et ideo videmus quod statim cum materia est disposita per alterationem praecedentem, forma substantialis acquiritur materiae, et eadem ratione, quia diaphanum est secundum se dispositum ad lumen recipiendum, subito illuminatur a corpore lucido in actu. Dictum est autem supra quod Deus ad hoc quod gratiam infundat animae, non requirit aliquam dispositionem nisi quam ipse facit. Facit autem huiusmodi dispositionem sufficientem ad susceptionem gratiae, quandoque quidem subito, quandoque autem paulatim et successive, ut supra dictum est. Quod enim agens naturale non subito possit disponere materiam, contingit ex hoc quod est aliqua disproportio eius quod in materia resistit, ad virtutem agentis, et propter hoc videmus quod quanto virtus agentis fuerit fortior, tanto materia citius disponitur. Cum igitur virtus divina sit infinita, potest quamcumque materiam creatam subito disponere ad formam, et multo magis liberum arbitrium hominis, cuius motus potest esse instantaneus secundum naturam. Sic igitur iustificatio impii fit a Deo in instanti.' Already at 110.2 resp.: 'sicut iam dictum est, in eo qui dicitur gratiam Dei habere, significatur esse quidam effectus gratuitae Dei voluntatis. Dictum est autem supra quod dupliciter ex gratuita Dei voluntate homo adiuvatur. Uno modo, inquantum anima hominis movetur a Deo ad aliquid cognoscendum vel volendum vel agendum. Et hoc modo ipse gratuitus effectus in homine non est qualitas, sed motus quidam animae, actus enim moventis in moto est motus, ut dicitur in III Physic. Alio modo adiuvatur homo ex gratuita Dei voluntate, secundum quod aliquod habituale donum a Deo animae infunditur. Et hoc ideo, quia non est conveniens quod Deus minus 
a-successionality of it all, suggesting once again a discourse attuned less to time than to being as a dominant parameter of consciousness, should not be allowed to waylay us here, for Dante's, in the Commedia, is not, in fact, an essay in the entitative and in the strangeness thereof, but rather in the opening out of self upon what it already has it in itself to be and to become, on the kind of greater humanity, or 'transhumanity', present to it from beforehand as at once the innermost and 'ownmost' ('eigenst') of its proper possibilities. His, in other words, is the logic and lexis, not of modification, but of emergence, of a progressive and progressively ecstatic process of self-implementation; so, for example, with their talk of dilation ('dilatarsi'), of 'magnification' ('farsi più grande') and of 'issuing forth' ('di sé uscire') as a way of seeing and celebrating the process of drawing nigh (the 'appropinquare' of Par. XXXIII.47), these lines (34-45) from Paradiso XXIII:

Oh Bëatrice, dolce guida e cara!

Ella mi disse: "Quel che ti sobranza

è virtù da cui nulla si ripara.

Quivi è la sapïenza e la possanza ch'aprì le strade tra 'l cielo e la terra, onde fu già sì lunga disïanza".

Come foco di nube si diserra per dilatarsi sì che non vi cape, e fuor di sua natura in giù s'atterra, la mente mia così, tra quelle dape fatta più grande, di sé stessa uscìo, e che si fesse rimembrar non sape. ${ }^{32}$

provideat his quos diligit ad supernaturale bonum habendum, quam creaturis quas diligit ad bonum naturale habendum. Creaturis autem naturalibus sic providet ut non solum moveat eas ad actus naturales, sed etiam largiatur eis formas et virtutes quasdam, quae sunt principia actuum, ut secundum seipsas inclinentur ad huiusmodi motus. Et sic motus quibus a Deo moventur, fiunt creaturis connaturales et faciles; secundum illud Sap. VIII, et disponit omnia suaviter. Multo igitur magis illis quos movet ad consequendum bonum supernaturale aeternum, infundit aliquas formas seu qualitates supernaturales, secundum quas suaviter et prompte ab ipso moveantur ad bonum aeternum consequendum. Et sic donum gratiae qualitas quaedam est.' Otherwise, $D e$ verit. 28. 9, sed contra 1 and resp. ult.: 'Iustificatio impii est quaedam spiritualis illuminatio. Sed illuminatio corporalis fit in instanti, non in tempore ... Nam forma et dispositio ad formam completam et abiectio alterius formae, totum est in instanti.'

32 O Beatrice, sweet guide and dear! She said to me, "That which overcomes you is power against which naught defends itself. Therein are the wisdom and the power that opened the roads between heaven and earth, for which of old there was such long desire". Even as fire breaks from a cloud, and dilates so that it has not room there, and contrary to its own nature, falls down to earth, so my mind, becoming greater amid those feasts, issued from itself, and of what it became has no remembrance. 
or, with their talk of soaring and strengthening ('sormontare' and 'avvalorarsi') as the way of ultimate affirmation, these (lines 52-63 and 106-14) from Cantos XXX and XXXIII:

"Sempre l'amor che queta questo cielo accoglie in sé con sì fatta salute, per far disposto a sua fiamma il candelo".

Non fur più tosto dentro a me venute queste parole brievi, ch'io compresi me sormontar di sopr' a mia virtute;

e di novella vista mi raccesi tale, che nulla luce è tanto mera, che li occhi miei non si fosser difesi;

e vidi lume in forma di rivera fulvido di fulgore, intra due rive dipinte di mirabil primavera. ...

Omai sarà più corta mia favella, pur a quel ch'io ricordo, che d'un fante che bagni ancor la lingua a la mammella.

Non perché più ch'un semplice sembiante fosse nel vivo lume ch'io mirava, che tal è sempre qual s'era davante;

ma per la vista che s'avvalorava in me guardando, una sola parvenza, mutandom' io, a me si travagliava. ${ }^{33}$

Now the soul's movement into God is indeed a movement into the strangeness of God, into the a-referentiality - the timelessness, spacelessness, everywhereness and nowhereness - of what is as of the essence. But for all the strangeness of that movement into God, there can be no question here of a metaphysical or magical co-adaptation of the subject to the object of its desiring, grace, far from modifying the individual at the level of form (albeit of accidental form) and thus in some sense modifying

\footnotetext{
33 "Ever does the love which quiets this heaven receive into itself with such like salutation, in order to prepare the candle for its flame." No sooner had these brief words come within me than I comprehended that I was surmounting beyond my own power, and such new vision was kindled in me that there is no light so bright that my eyes could not have withstood it. And I saw a light in the form of a river glowing tawny between two banks painted with marvelous spring ... Now will my speech fall more short, even in respect to what I remember, than that of an infant which still bathes his tongue at the breast. Not because more than one simple semblance was in the living light wherein I was gazing, which is ever such as it was before; but through my sight, which was growing strong in me as I looked, one sole appearance, even as I changed, was altering itself to me.
} 
the original project, serving rather to confirm it in its natural capacity for self-transcendence as the most immanent of its immanent possibilities. This, then is the third great work of grace in its positive verification. The third great work of grace in its positive verification is the confirming of self in the power to transhumanity, transhumanity, for Dante, being but humanity under the aspect of ecstasy.

4. Adolph Harnack, the great German historian of Christian dogmatics, pauses in a moment of melancholy to consider the gap in medieval theology between God and grace, between on the one hand the superabundant love which is God, and, on the other, grace as that whereby that same love is known to man under the conditions of time and space. There was, he says, among the great theological spirits of the Middle Ages

no recognition of personality, neither of the personality of God, nor of man as a person. If even in earthly relations man cannot be otherwise raised to a higher stage, than by passing into a person who is superior, more mature, and greater, that is, by entering into spiritual fellowship with such an one, and attaching one's self to him by reverence, love, and trust, then the same holds good, but in a way that transcends comparison, of the rising of man from the sphere of sin and guilt into the sphere of God. Here no communications of things avail, but only fellowship of person with person; the disclosure to the soul, that the holy God who rules heaven and earth is its Father, with whom it can, and may, live as a child in its father's house - that is grace, nay, that alone is grace, the trustful confidence in God, namely, which rests on the certainty that the separating guilt has been swept away. That was seen by Augustine as little as by Thomas, and it was not discerned even by the medieval Mystics, who aspired to having intercourse with Christ as with a friend ; for it was the man Jesus of whom they thought in seeking this. But all of them, when they think of God, look, not to the heart of God, but to an inscrutable Being, who, as He has created the world out of nothing, so is also the productive source of inexhaustible forces that yield knowledge and transformation of essence. And when they think of themselves, they think, not of the centre of the human ego, the spirit, which is so free and so lofty that it cannot be influenced by benefits that are objective, even though they be the greatest perceptions and the most glorious investiture, and at the same time is so feeble in itself that it can find support only in another person. Therefore they constructed the thesis: God and gratia (i.e., knowledge and participation in the divine nature), in place of the personal fellowship with God, which is the gratia. That gratia, only a little separated from God in the thesis, became in course of time 
always further removed from Him. It appears deposited in the merit of Christ, and then in the Sacraments. But in the measure in which it becomes more impersonal, more objective, and more external, confidence in it is also impaired, till at last it becomes a magical means, which stirs to activity the latent good agency of man, and sets in motion the standing machine, that it may then do ito work, and that its work may be of account before God. ${ }^{34}$

Now this, in so far as it holds good in respect of a literature endlessly nuanced in respect of the substance and psychology of grace as the means of renewal and of resurrection, and indeed of the precise nature of man's relationship with God under the conditions of the time and space, is indeed melancholy. But in so far as it touches on Dante, it helps to account for his relative indifference, not, certainly, to grace precisely as such (on the contrary!), but to anything resembling a theology of grace. Faith, hope, love, atonement, election, yes, all these and much else besides are there as a matter of systematic concern, but not grace. How, then, are we to account

${ }^{34}$ A. Harnack, History of Dogma, trans. N. Buchanan (New York: Dover Publications, 1961), vol. 6, pp. 279-80. John Burnaby, however (Amor Dei. A Study of the Religion of St Augustine (The Hulsean Lectures for 1938) (London: Hodder and Stoughton, 1938), p. 313), commenting on Nygren's position in his Agape and Eros, Part II, The History of the Christian Idea of Love (London: SPCK, 1954) is gentler in Augustine's regard, seeing there a more intimate association between the notion of grace and the working of the Spirit: 'It is a conspicuous merit in Nygren's treatment of Augustine to have decisively rejected the superficial criticism which alleges that the Catholic doctrine of grace - as distinct from perversions of practice - is "magical" or "mechanical". What St Thomas calls the "infusion" of charity is that same working of the Holy Spirit for which Augustine found his Locus classicus in the Epistle to the Romans. It is no 'thing-like' substance introduced from without, but the purely spiritual influence of the divine Person whose dwelling is within the believer's heart.' Nygren's text (pp. 522-23) runs as follows: 'This idea of the infusion of grace and love (infusio caritatio) has often been taken to prove that Augustine's conception of grace was magical and naturalistic. Thus Harnack says: "The love of God is infused into the soul in portions." The root error of Augustine's doctrine of grace is supposed to lie in its "objective character" (ihres dinglichen Charakters); indeed, he is accused of believing that "love can be poured in like a medicine". Similarly, W. Herrmann finds the weakness of Augustine's idea of grace in the fact that he failed to make it psychologically intelligible how man is converted by the grace of God which meets us in the historical Christ, and was content to think of grace as a mysterious power. But here the need for caution is indicated by the very fact that Augustine's idea of the "infusion" of Caritas is directly connected with Paul's saying in Rom. v.5 that "the love of God hath been shed abroad in our hearts through the Holy Ghost which was given unto us". Nothing was further from Augustine's intention than a magical or naturalistic idea of grace. If we are to apply the alternative "magical and naturalistic" or "personal and psychological", then it is the latter that describes Augustine's view. Caritas is infused into our hearts, not in a manner that is unconnected with our relation to God, but by the fact that the Holy Spirit is given to us.' 
for this situation? By way of the status of grace in Dante as but love by another name, at which point motion, remotion, magic and metaphysics, indeed the entire apparatus of high-scholastic grace-consciousness, give way to something simpler and more sublime. 